\title{
Science is universal, not part of any religion
}

\section{Islam fostered its rise and can be proud that it has now grown beyond any one culture.}

Sir - In your Opinion article "Fighting against terrorism, engaging with Islamic science" (Nature 413, 235; 2001) you tell readers that, as scientists, we can do more for the societies engaged in the present "conflict" (a noble euphemism for an unprovoked attack on civilians), and that the indiscriminate killing of innocents is not the consequence of a clash of civilizations.

You state: "many Islamic scholars and leaders have emphasized that the murder of the innocent is as offensive to their beliefs as to anyone else's". Surely the evil of killing people is self-evident and hardly requires a restatement by scholars and leaders, whether Islamic or Icelandic? You go on to say: "resurgent Islam appears to be giving a sense of values ... to populations ... repressed within their countries" and that revolutionary intent (or what others would call 'terrorism') is the pastime of only some activist groups. In plain English, you are telling us that one should have understanding for those whose cultural identity is enhanced by flying passenger aircraft into skyscrapers.

Your article provides URLs for two websites as part of your analysis of the conflict between Islamic and Western science. The first contains an original and unbiased discussion of the issue by $\mathrm{Dr}$ Mehrzad Boroujerdi; the second is a poorly reproduced speech, based on lecture notes, markedly political and rhetorical in character, but hardly a scholarly document.

Most educated people know that Islamic science is responsible for one of the major events in the history of civilization: the passing on of the Greek science of antiquity to mediaeval Europe. By doing this, Islamic science was not merely a messenger but an active generator of a scientific revolution without which Europe might never have entered the Renaissance. From algebra to algorithm, Islamic science left an indelible print on the Western scientific edifice. This was supplemented by its tolerance for and nurturing of nonIslamic cultures, as demonstrated by the unprecedented flowering of Hebrew scholarship and poetry in Arabic Spain.

But what is meant by Islamic science in the year 2001? Is there Islamic chemistry or Islamic quantum mechanics? I do not think so. I admire and respect an Arab biologist who does superb work in my field, and a geneticist colleague of mine collaborates with Palestinian physicians on a healthrelated project, even while the guns are roaring. I admire the Arab fellow-scientist because he is first-class, not because he is a representative of Islamic science - a classification I am certain he would abhor. Your preaching that we should prevent the killing of innocents by "engaging with Islamic science" is a crass example of neocolonialist paternalism and an offence to scientists labelled as Islamic. My ancestors made a modest contribution to the compilation of the Bible, but this does not mean that I live by the principle of an eye for an eye; neither did my British Christian colleagues offer the other cheek when threatened by Nazi rule.

The proposal that fostering collaboration between Islamic and Western

\section{Don't use terrorism as an excuse for militarism}

Sir - In your Opinion article "Antiterrorist agendas" (Nature 413, 655; 2001) you seem to have swallowed whole the assumptions about a new 'war' promoted by the Bush administration. You discuss how the science community may assist its governments in what I consider a false war.

Your article states: "In times of war, modern governments require a special relationship with their best scientists and engineers - a relationship which now needs to be recast."

But to have a war there has to be an adversary much more specific and less elusive than the terrorists whom the administration is condemning. In my view the so-called "war" is really an openended mobilization for the self-interests of the Bush administration: increased support for the military, increased presence in south-west Asia, decreased civil rights, decreased social spending, muzzling of opposition and blanketing of information.

It is unfortunate that, to promote science, Nature believes that we must accede to the politics of an uncivil society. The charge that science and militarism go hand in hand seems here to be borne out. This will only harm science in the long run. Morton K. Brussel

Loomis Laboratory of Physics, University of Illinois at Urbana-Champaign, 1110 West Green Street, Urbana, Illinois 61801, USA

\section{BSE record set straight}

Sir - It was disappointing that your reporter contributed further confusion to the issue of cow brains being tested instead of sheep brains for signs of BSE ("Brain scientists is an effective means in the fight against terrorism should be first and foremost rejected by those who have been so carelessly categorized as "Islamic" scientists. An international gang of wellfinanced criminals, using the cream of Western science for the sole purpose of indiscriminate killing, has as little to do with Islamic science as the Boston Strangler has with America's founding fathers.

Edgar Pick

Julius Friedrich Cohnheim-Minerva Centre for Phagocyte Research, Sackler School of Medicine, Tel Aviv University, Tel Aviv 69978, Israel mix-up leaves BSE research in turmoil”, Nature 413, 760; 2001) by failing to contact the Laboratory of the Government Chemist (LGC) before declaring that our findings in this case were open to dispute.

To set the record straight, LGC is an independent, non-Government laboratory committed to the highest standards of analytical quality.

We have developed, validated and deployed DNA-based tests for the speciation of meat for many years, often in cases of commercial misdescription of processed meat. The Department for the Environment, Food and Rural Affairs (DEFRA) commissioned LGC to check the species identity of the brain samples that were used in the BSE experiments conducted by the Institute of Animal Health (IAH).

Our tests used two different extraction methods, three methods for qualitative identification and a full battery of controls, blanks and authentic samples.

We were aware that the IAH samples had already been subjected to a number of cycles of freeze-thawing, so the experiments were specifically designed to be able to detect degraded DNA (about 220 base pairs). The identification of beef DNA was unambiguous. (Our report to DEFRA is available on the LGC website, www.lgc.co.uk.)

The assertion in Nature that the storage conditions of the samples in transit to LGC could have affected the results does not bear scientific examination. DNA is a robust molecule, and it would be a remarkable sequence of freezing and thawing that turned sheep DNA into beef.

\section{Richard Worswick}

Laboratory of the Government Chemist,

Queens Road, Teddington,

Middlesex TW11 OLY, UK 